\title{
A Case of Chronic Lymphocytic Leukemia in Two Brothers
}

İlhami GÜLTEPE', Tuba ÖZKAN¹, Güven ÇETIN²

${ }^{1}$ Department of Internal Medicine, Bezmialem Vakıf University, İstanbul, Turkey

${ }^{2}$ Department of Hematology, Bezmialem Vakıf University, İstanbul, Turkey

\section{ABSTRACT}

Monoclonal B-cell lymphocytosis is accepted as an important risk factor for developing lymphocytosis familial chronic lymphocytic leukemia (CLL) but does not meet the criteria for B-cell lymphoproliferative disease, and patients with <5,000 (but not 0) CLL-phenotype B-cell lymphocytes per $\mathrm{mm}^{3}$. Individuals with lymphocytosis who have relatives diagnosed with CLL should undergo flow cytometry for early diagnosis. In our study, a 56-year-old patient's brother had been early diagnosed with CLL and with lymphocytosis, and the patient was diagnosed with class 1-2 CLL after 2 years. We emphasize that individuals having a family history of CLL should be closely monitored.

Keywords: Chronic lymphocytic leukemia, familial form, monoclonal B-cell lymphocytosis

\section{Introduction}

Chronic lymphocytic leukemia (CLL) is a lymphoproliferative disorder of monoclonal origin, and it is characterized by increased number of lymphocytes with insufficient function. It is considered among indolent non-Hodgkin lymphomas with mature B-cell small lymphocytic lymphoma (1). While CLL constitutes approximately $30 \%$ of all leukemia cases in the Western countries, its incidence has been reported to be about 4/100,000 in the United States and 5/100,000 in Europe. On the other hand, CLL is seen less commonly in Asian countries and Japan. The ratio of females to males with CLL is 1:2. Similar rates have been found in the retrospective studies conducted in our country, and the mean age has been reported to be $63 \pm 2$ years. However, analyses of patients show that CLL is also seen in young population ( $<45$ years) (2).

Although the etiology of CLL is not known exactly, it is suggested that CLL is associated with environmental factors such as radiation, infectious factors, and exposure to toxic drugs and chemicals. However, indifference in the incidence of the disease among Asian immigrants who live in America shows that genetic factors and/or lifestyle can also be effective in the development of the disease as well as environmental factors (3). Genetic susceptibility in CLL has been supported by the presence of many CLL cases in some families (4).

Lymphoid, hematological, and solid tumor malignancies are seen more commonly than expected among the relatives of patients followed due to the diagnosis of CLL (5). Moreover, in comparison with the relatives of a healthy group, a significant increase has been found in the risk for the development of CLL. In addition to these malignancies, another clinical condition that is more common among the first-degree relatives of CLL patients and characterized by a lower rate of B-cell growth despite its clinical similarity to CLL is monoclonal B-cell lymphocytosis (MBL) (5). However, it is thought that the presence of MBL with an asymptomatic course among relatives of CLL patients is also an important risk factor for the development of CLL (6).

There are insufficient documents on the clinical features of familial CLL. However, no prominent difference has been reported between the clinical features and prognostic markers of familial CLL and sporadic CLL (7). In a study on the

\footnotetext{
Address for Correspondence: Ilhami CÜLTEPE; Bezmialem Vakıf Üniversitesi, l̇ç Hastalıkları Anabilim Dalı, İstanbul, $\quad$ Received 02.02 .2016 Türkiye E-mail:drigultepe@gmail.com

Accepted : :25.04.2016
} 
familial histories of 1449 patients with the diagnosis of CLL, there was no apparent difference except that familial CLL was observed to be more common in women (7).

In this study, we present a newly diagnosed CLL patient who presented to our clinic with lymphadenopathy (LAP) and whose brother was being followed up for CLL.

\section{Case Presentation}

The patient signed a written informed consent form for his medical data to be used in medical articles and journals.

A 56-year-old male patient was admitted to our outpatient clinic due to the complaint of swelling in his neck. The patient had no history of any chronic disease, but it was learned that his brother had been diagnosed with stage $0-1$ CLL 5 years ago and was being followed up without any medication. The patient's physical examination revealed multiple LAPs, the largest of which was $20 \times 10 \mathrm{~mm}$, in his neck and dullness in the Traube's space. Other systemic examination results were found to be normal. Lymphocyte dominance was observed in his peripheral smear, and no atypical cells were found. The results of the laboratory analyses were as follows: $\mathrm{Hb}: 13.5 \mathrm{~g} / \mathrm{dL}$; Plts: $164,000 / \mu \mathrm{L}$;

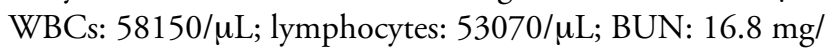
$\mathrm{dL}$; creatinine: $0.7 \mathrm{mg} / \mathrm{dL}$; Na: $137 \mathrm{mmol} / \mathrm{L} ; \mathrm{K}: 4 \mathrm{mmol} / \mathrm{L}$; Ca: $8.8 \mathrm{mg} / \mathrm{dL}$; T. Protein: $7.1 \mathrm{~g} / \mathrm{dL}$; albumin: $4.1 \mathrm{~g} / \mathrm{dL}$; AST: 19 U/L; ALT: 11 U/L; GGT: 10 U/L; ALP: 98 U/L; T. Bilirubin: $0.4 \mathrm{mg} / \mathrm{dL}$; D. Bilirubin: $0.09 \mathrm{mg} / \mathrm{dL}$; ESR: $8 \mathrm{~mm} /$ sa; CRP: $0.1 \mathrm{mg} / \mathrm{L}$; INR: 1.2 ; viral serology: negative; serum IgA, IgG, and IgM levels: normal. In his peripheral blood flow cytometry, proliferation of monotypic B lymphocytes, which constitute $94 \%$ of lymphocytes and display CD19++, CD 20+, CD22+, CD5+, CD23+, CD43+, DR+, sIg+, and Kappa+ immunophenotypes, was detected. Bone marrow aspirate smear revealed lymphocyte dominance at the rate of $60 \%$ without increased prolymphocytes. The karyotype analysis revealed 46XY karyotype, and chromosome analysis revealed no chromosomal anomaly. Bone marrow biopsy was consistent with CLL considering immunophenotypic and morphologic findings. Computed tomography showed multiple LAPs, the largest of which was $24 \times 15 \mathrm{~mm}$, in the neck, thorax, and abdomen and splenomegaly (size of spleen, $163 \mathrm{~mm}$ ). The patient, who had shown lymphocyte dominance in the examinations performed 2 years ago, was considered as having stage 2 CLL according to the RAI staging system. Based on the present findings and clinical condition, it was decided to follow-up the patient without any treatment at 3-month intervals in the outpatient clinic of hematology. In his control examination performed at the end of the first year, it was found that his laboratory values were stable.

\section{Discussion}

CLL is a disorder that is the most common one among leukemia forms and affects approximately $2 \%$ of the population. Its familial subtype is seen in at least one of the family members, which differentiates it from sporadic cases (4). Epidemiological studies showing that the risk of CLL is three to seven times higher in the families of affected individuals have helped well recognize the familial form of the disease and have revealed that the familial form constitutes $5 \%$ of the CLL patient group (8).

Although genetic factors are responsible for the development of the familial form, environmental factors have also been demonstrated to be effective. In studies examining genetic structures of families with CLL, it was found that the members of these families had many other lymphoproliferative disorders (Hodgkin and non-Hodgkin lymphoma, Waldenström macroglobulinemia, MBL) in addition to CLL (4). Pedigree analyses showing the heritability in distant relatives suggest that shared genes account for variant B-cell malignancies. However, these analyses cannot be explained just with a genetic transition (9). In a study in the area of genetic epidemiology, it was found that affected regions were in chromosomes $1 \mathrm{q}$, $3 q, 6 q, 12 q$, and $13 q$ in one of the family members and in chromosomes $11 \mathrm{p} 11,5 \mathrm{q} 22-23,6 \mathrm{p} 22,10 \mathrm{q} 25$, and $14 \mathrm{q} 32$ in another member. However, no prominent germline mutation was detected in these regions (4).

Despite all these unknown sides in its etiology, frequent use of flow cytometry in practice has revealed that the presence of a CLL-phenotype B-cell population in peripheral blood is encountered more commonly in individuals with two or more CLL diagnoses in their families compared with healthy individuals (7). MBL, which is characterized by a monoclonal B-cell count of $<5000 / \mathrm{mL}$ in peripheral blood without clinical signs and findings related to B-cell lymphoproliferative disorders, is also accepted to be an important risk factor for the development of familial CLL. It requires a close follow-up because it is seen in $<1 \%$ of adults and $4 \%-5 \%$ of individuals aged 40 years and above, but it is more common (10\%) in the relatives of CLL patients (1). Considering non-CLL cases (CD5- and CLL-phenotype B-cell populations) evaluated in MBL classification, it is important to follow-up the patients with lymphocytosis and familial histories of CLL using flow cytometry (10).

Our presented case was considered to be that of familial CLL because of the presence of CLL in his brother. The examination of this patient, whose brother had been diagnosed with CLL 5 years ago, had revealed lymphocytosis without any clinical signs and findings 2 years ago, and this was accepted to be significant in terms of MBL. In this study, the importance of follow-up with regard to MBL and familial CLL was emphasized for patients who had no active complaint but were incidentally found to have lymphocyte dominance and had a familial history of CLL.

Informed Consent: Written informed consent was obtained from patients who participated in this study.

Peer-review: Externally peer-reviewed. 
Author Contributions: Concept - G.Ç.; Design - G.Ç.; Supervision - İ.G.; Funding - T.Ö.; Materials - T.Ö.; Data Collection and/or Processing - T.Ö.; Analysis and/or Interpretation - İ.G.; Literature Review - İ.G.; Writing - İ.G.; Critical Review - İ.G.

Conflict of Interest: No conflict of interest was declared by the authors.

Financial Disclosure: The authors declared that this study has received no financial support.

\section{References}

1. Soysal T. Kronik Lenfositik Lösemi- Küçük Lenfositik Lenfoma, in Türk Hematoloji Derneği Hematolog. 201. p. 253-270.4. Pamuk, G.E., Ö.N. Pamuk, T. Soysal, Ş. Öngören, Z. Başlar, B. Ferhanoğlu, et al. An Overview Of Young CLL Patients: A Single-Centre Experience From Turkey. Haematologia 2001; 31: 303-11. [CrossRef]

2. Howlader, N., A. Noone, M. Krapcho, N. Neyman, R. Aminou, S. Altekruse, et al. Seer Cancer Statistics Review, 1975-2009 (Vintage 2009 Populations). Bethesda, Md: National Cancer Institute; 2012. 2012, Apr.

3. Pang JWY, Cook LS, Schwartz SM, Weiss NS. Incidence Of Leukemia In Asian Migrants To The United States And Their Descendants. Cancer Causes \& Control 2002; 13: 791-5. [CrossRef]
4. Goldin LR, Slager SL. Familial CLL: Genes And Environment. ASH Education Program Book, 2007. 2007: 339-45.

5. Goldin LR, Lanasa MC, Slager SL, Cerhan JR, Vachon CM, Strom SS, et al. Common Occurrence Of Monoclonal B-Cell Lymphocytosis Among Members Of High-Risk Cll Families. Br J Haematol 2010; 151: 152-8. [CrossRef]

6. Damle RN, Calissano C, Chiorazzi N. Chronic Lymphocytic Leukaemia: A Disease Of Activated Monoclonal B Cells. Best Pract Res Clin Haematol 2010; 23: 33-45. [CrossRef]

7. Mauro FR, Giammartini E, Gentile M, Sperduti I, Valle V, Pizzuti A, et al. Clinical Features And Outcome Of Familial Chronic Lymphocytic Leukemia. Haematologica 2006; 91: 1117-20.

8. Houlston RS, Sellick G, Yuille M, Matutes E, Catovsky D. Causation Of Chronic Lymphocytic Leukemia-Insights From Familial Disease. Leukemia Research 2003; 27: 871-6. [CrossRef]

9. Goldin LR, Landgren O, Marti GE, Caporaso NE. Familial Aspects Of Chronic Lymphocytic Leukemia, Monoclonal B-Cell Lymphocytosis $(\mathrm{Mbl})$, And Related Lymphomas. European Journal Of Clinical \& Medical Oncology 2010; 2: 119.

10. Ahmad E, Steinberg SM, Goldin L, Hess CJ, Caporaso N, Kreitman RJ, et al. Immunophenotypic Features Distinguishing Familial Chronic Lymphocytic Leukemia From Sporadic Chronic Lymphocytic Leukemia. Cytometry B Clin Cytom 2008; 74: 221-6. [CrossRef] 